\title{
COMUNICAÇÃO NÃO-VERBAL
}

Para transmitir uma idéia é necessário transformar o pensamento em um ato linguístico por meio de mensagens, constituídas de um ou mais signos. O americano Charles Peirce classificou os signos segundo seu grau de convencionalidade: símbolos (signos impregnados de aspectos culturais), ícones (que lembram aquilo que representam) e índices (naturais e marcados pela não intenção). Alguns autores europeus, como Buyssens, excluem os índices, pois consideram comunicação apenas quando existe intenção; já outros, como Barthes e Thayer, ampliam os fenômenos da significação para tudo aquilo que for relevante para o destinatário, não importando se houve intencionalidade. Os livros selecionados por Roseli Morena Porto - professora da FGV-EAESP - apresentam os estudos dos índices na linguagem não-verbal como um importante recurso na estratégia de comunicação empresarial.
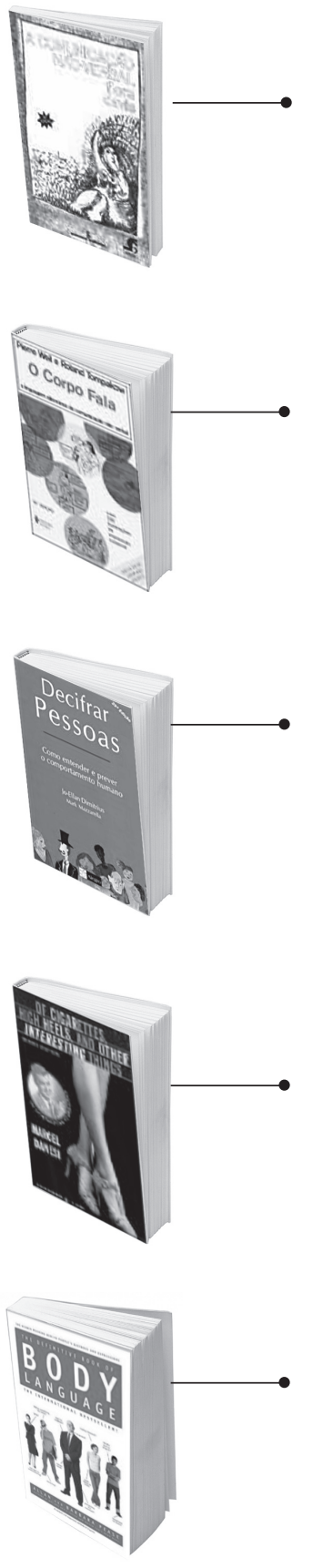

A COMUNICAÇÃo NÃO-VERBAL. Flora Davis. São Paulo: Summus, 1979. 196 p.

Em linguagem jornalística, a autora traduz os esforços de inúmeros cientistas sociais que nos anos 1970 concentravam suas pesquisas para romper o código não-verbal. O livro trata a comunicação verbal e a não-verbal como inseparáveis, tecidas juntas pelos seres humanos quando estão face a face. Essa comunicação ocorre em muitos níveis simultâneos, consciente e inconscientemente, usando para isso todos os sentidos. Alguns capítulos descrevem como as partes do corpo e respectivos movimentos integram a mensagem. Ao final, uma ampla bibliografia permite o aprofundamento nos aspectos mais interessantes.

O CORPO FALA: a linguagem silenciosa da comunicação não-verbal. Pierre Gilles Weil e Roland Tompakow. São Paulo: Vozes, 1986. 288 p.

Pierre Weil, psicólogo, e Roland Tampakow, artista gráfico, ambos educadores, comparam a esfinge ao corpo humano para decodificar a expressão corporal. Composta por quatro partes, corpo de boi, tórax de leão, asas de águia e cabeça de homem, que corresponderiam, respectivamente, às vidas: instintiva e vegetativa (desejos), emocional (sentimentos) e mental (pensamentos), cabendo ao homem o domínio dos três conscientes anteriores. Partindo das antigas origens dos gestos de hoje, as ilustrações ensinam a observar as partes do corpo para decifrar as mensagens silenciosas.

DECIFRAR PESSOAS: Como entender e prever o comportamento humano. Jo-Ellan Dimitrius e Mark Mazarella. São Paulo: Elsevier, 2003. 328 p.

Os autores, com mais de 20 anos de experiência na área jurídica, mostram que em um julgamento a composição dos jurados e a escolha das testemunhas são tão importantes quanto a estratégia de argumentação. O livro leva para o cotidiano a técnica de reconhecimento de padrões na aparência, linguagem corporal, voz e conduta, testada nos tribunais em mais de 10 mil pessoas. Decifrar pessoas não é uma ciência nem um dom inato: é uma questão de saber o que olhar e ouvir, de ter a curiosidade e a paciência para reunir a informação necessária.

OF CIGARETTES, HIGH HEELS, AND OTHER INTERESTING THINGS: An introduction to semiotics. Marcel Danesi. New York: St. Martin's Press, 2008. 215 p.

Por que alguns espécimes humanos colocam a vida em risco fumando cigarros? Por que algumas mulheres se sacrificam usando sapatos de salto alto? Em linguagem acessível, o professor da Universidade de Toronto identifica como a utilização de objetos e comportamentos arriscados está relacionada à busca do significado dos signos que compõem uma cultura e sociedade. Para demonstrar como os objetos do dia-a-dia podem ser utilizados como um meio de comunicação não-verbal, o autor faz uma análise semiótica de um casal jantando em um restaurante.

THE DEFINITIVE BOOK OF BODY LANGUAGE. Barbara Pease e Allan Pease. New York: Bantam Books, 2006. 386 p.

Os autores são especializados no uso da linguagem corporal nas áreas política e de negócios, utilizando conceitos da biologia, psicologia e medicina em uma perspectiva evolucionista. Para eles, o homem moderno é menos eficiente do que seus ancestrais na decodificação da linguagem corporal, pois as palavras são uma fonte de distração. As ilustrações que acompanham o texto auxiliam o aprendizado do vocabulário básico da comunicação não-verbal, que inclui diferenças culturais de gesticulação; sinais secretos dos óculos; cigarros e maquiagem; mobiliário nos escritórios; territórios e espaços pessoais. 